\title{
It NeVer Happened: Kinguri's EXodus AND ITS CoNSEQUences
}

\author{
JAN VANSINA \\ UNIVERSITY OF WISCONSIN-MADISON
}

The later precolonial history of a vast area in west central Africa between the Kwango and the Lubllash rivers starts with-and is dated by - the tradition of exodus of Kinguri and his companions from the heartland of the Lunda commonwealth. ${ }^{1}$ For the last two decades, however, several scholars have claimed that this tradition is merely a later addition to the older body of the traditions told by a dozen or so different peoples in west central Africa. Yet so far no one has examined where and when and how the Kinguri exodus tradition could have grafted itself onto the traditions of so many peoples over such a vast area. If true, this claim also requires a radical revision of the accepted history of western Lunda expansion. To examine the claim and its consequences is the aim of this article, which begins with the earliest written report of the Kinguri's exodus story.

In Lunda on the Nkalaany river lived chief Jamwo, his two sons and his one daughter... [He disinherits the sons and gives the emblems of state to his daughter] After the death of the old Jamwo the unmarried princess took over the government. Later one of her hunting expeditions was active between the Nkalaany and Lubilash river and met there Kibinda llunga, the third son of Tombo Mokulo. His skill as a hunter struck the Lunda and they convinced the son of the chief to come with them to their queen, whereupon she married him and he took over the government of the state under the name Jamwo. As chief Jamwo Kibinda carried out many successful wars against other chiefs in the Lunda country and conquered their lands and his followers now called him Mwata Jamwo, i.e., "Big Father lamwo." The name "Matiamwo," now usual in Lunda country, stems from this "Mwata Jamwo," in that the Kalunda tie the two names together in a single word. A chief of the Lunda kingdom, who did not want to be subjected, fled with his followers west of the Quango river in the territory of the Europeans. At the time when the Portuguese government was fighting with queen Cinja [Njinga] on the Quanza river, this fleeing chief, by name of Kinguri, asked the government to give

1 Usually "Lunda empire" in the literature. But the unity of the Lunda ensemble did not consist in more than the acceptance of the Mwaant Yaav as a ruler superior to others . Moreover, some of these polities were founded by Rund settlers. Hence by analogy "commonwealth" seems more appropriate than "empire."

History in Africa 25 (1998), 387-403. 
him land to settle and the government attributed the present-day country of Kassange as the place where he and his followers could settle. ${ }^{2}$

This is the earliest known written version of the famous tradition relating the founding of the Lunda commonwealth: namely, the seduction of Rweej, the Lunda queen who married Kibinda Ilunga, and the flight of Kinguri to Angola. A few years later Henrique de Carvalho told the same tale in circumstantial and florid detail and also told how other chiefs also fled with Kinguri or left later as pursuers of Kinguri to become the founders of the other main kingdoms of the later Lunda commonwealth. Such was the appeal and the detail of this version that it became the standard account of the tradition concerning the origins of the Lunda empire. ${ }^{3}$

As this tradition linked the origins of the Lunda commonwealth to datable Portuguese activities in Angola, as well as to the creation of the kingdom of Cassange in Angola, it became the historiographical anchor for the chronology of a huge area in west central Africa, including the first emergence of the core polity of the commonwealth, the Rund kingdom, as well as the date for the beginnings of Lunda expansion, because the Kinguri tradition conflates both processes. After much debate and as the early history of Portuguese Angola and of the Imbangala, inhabitants of Cassange, became better known, Joseph Miller concluded that a titleholder named Kinguri probably arrived in Angola ca. 1550, so that one can estimate the departure of this group from the Rund heartland at the latest to $\mathrm{ca} \cdot 1490 .^{4}$

But this dating was soon disputed. Basing himself entirely on the chronology implicit in the kinglists, Jean-Luc Vellut concluded in 1972 that the kingdom began "maybe as far back as the late 17th century." He convinced Miller, who squared this conclusion with his earlier views by distinguishing between an incipient and a "mature" state of the Mwaant Yaav, and dated only the latter to the late

2 P. Pogge Im Reiche des Muata Jamwo (Berlin, 1880) 224-26; O. Schütt, Reisen im südzwestlichen Becken des Congo (Berlin, 1881) 79 (data from 1878/79), briefly mentions "Bangala Quinguri" as a kinsman of "Matiamvo" who helped the Portuguese against the queen of "Ginga oder N'Gola" and ousted the king of the Pende." The rest of his account makes evident that he derived it from a Portuguese source, probably Neves, discussed below.

3 H.A. Dias de Carvalho, Et/mographia e Historia tradicional dos povos da Lunda (Lisbon, 1890), 53-112, esp. 58-82.

4 J.C. Miller "The Imbangala and the Chronology of Early Central African History," JAH, 13 (1972), 570-74. His Kings and Kinsmen (Oxford 1976), 114-223, does not date this. Hence my own dating in P.D. Curtin et al, African History from Earliest Times to Independence (2d. ed.: London 1995), 226. 
seventeenth century. ${ }^{5}$ But he still accepted the Kinguri tradition as a genuine record of ancient times .

In 1972, however, the structuralist anthropologist Luc de Heusch radically rejected the historicity of the whole early Rund tradition, including Kinguri. ${ }^{6}$ A few years later Jeffrey Hoover, who had carried out intensive historical research in the Rund heartland and utilized linguistic analysis, dismissed the story of the exodus of Kinguri and his companions, but not the whole Rweej tradition. ${ }^{7}$ Without the Kinguri link, the chronology of Lunda history now rested on the well-documented eastern expansion into Katanga and Zambia which began $c a .1700$, a date all historians accept. ${ }^{8}$ Hoover also drew attention to the important distinction between an earlier core Rund kingdom and the later Lunda commonwealth. Working from kinglists as did Vellut, he now dated the onset of the Rund kingdom to the early seventeenth century. ${ }^{9}$ A few years later John Thornton also rejected the Kinguri exodus as a genuine tradition and dated the onset of Lunda expansion to 1700, while leaving the date for the founding of the Rund kingdom open: "This homeland was for years, perhaps for centuries, the location of a fairly modest state." 10

Given the considerable consequences inherent in a denial of the historicity of a Kinguri exodus from Lunda, it is well worth reviewing the evidence in more detail. At the outset one must remark that, despite a careful study of all the known seventeenthcentury records relevant to Jaga, Imbangala, and Ambundu, not a single African term has been found that can be shown to be of Rund or Cokwe origin. Hence the Kinguri exodus story does not receive any support from the only other possible source besides recorded oral traditions.

The earliest mention of Kinguri occurs in the record of Jaga traditions "according to their chants and tales" that Cavazzi or

5 J-L.Vellut, "Notes sur le Lunda et la frontière luso-africaine (1700-1900)," Etudes d'histoire africaine, 3 (1972), 65-69; Miller, Kings, 112n1.

- Luc de Heusch, Le roi ivre ou l'origine de l'état (Paris 1972).

7 Jeffrey Hoover, "The Seduction of Rweej" (PhD, Yale University, 1978), 157-175 for the historiography of the tradition; 211-43 for the rejection of the Kinguri exodus.

" Ibid., 244-87. The dating proposed for the earliest colony at Mukulweji is ca. 16701700 .

- Ibid., 238, and $c n .1600$ for the rule of Rweej.

11 John K. Thornton,"The Chronology and Causes of Lunda Expansion to the West, c.1700-1852,"Zambia Journal of History 1 (1981), 7. Thornton knew about, but did not have access to, Hoover's work. 
Serravezza noted down at the court of Kasanje before 1663." Cavazzi tells us this:

A certain Quinguri succeeded Culembe. He was a man worthy of his name, not because of his magnanimity but because of his ferocity: in fact $n$ guri means lion. ${ }^{12}$ In reality he was a ruthless highwayman, ferocious wherever he managed to go, avid of massacres, victims and blood. He entered into the kingdom of Dongo, which is called Angola today, and died there in combat. ${ }^{13}$

There is no mention at all of any migration from the far east. At most, one can note that his predecessor Culembe had conquered most of Matamba and that he may have entered Ndongo from the east. As the Jaga seem to have first invaded Ndongo-but from the southwest!-ca. 1612-18, this record would date only to forty years or so after these events. ${ }^{14}$ One may also keep in mind that Kinguri might have been a title, perhaps awarded posthumously.

The next mention of Kinguri occurs in an aside by Graça in 1843.

Kinguri was a child of the son of the queen Njinga on the father's side and of [lacuna] on his mother's side. Even today this title is claimed [reconhecido] by all the kings which I have mentioned ${ }^{15}$ and they derive their laws from him. ${ }^{16}$

He goes on to stress that the Jaga of Cassange stem from Kinguri and like the other potentates observe his cruel laws by ordering frequent human sacrifices.

Then comes a fuller version recorded by Neves at Cassange in 1850. Cassange tradition then started with "Quingure-quiabanguella" ("Kinguri of the Imbangala"?).

"Ibid., 11n10. Cavazzi visited Cassange from 1660 and may also have received further information from Antonio da Serravezza, who lived at Cassange's court from 1655 to 1659. Cf. G. Saccardo, Congo e Angola (3 vols.: Lisbon, 1982), 1: 504-05, 523 , 524. Hence the record of the traditions dates most likely from 1655-60.

12 This meaning occurs in the Wambo variant of Ovimbundu. Cf. Miller, "Imbangala," 565 n63, and other dictionaries. In modern Kimbundu dictionaries Kinguri means "forefather," "begetter," "procreator," "root," etc., and nguri or nguri ana, "trunk of descent," i.e., the person from whom a family descends. The earliest reference I could find, however, occurs in J.D. Cordeiro da Matta, Ensaio de Diccionario Kimbundu-Portuguez (Lisbon 1893), 125: nguriana: "mãe de filhos." In Kongo (1650) "gudi/nguri meant "mother (in general)" and with -ankama , "master, lord." In modern Kongo the term means "mother, age, authority" and "clan or family."

${ }_{13}$ J.A.Cavazzi de Montecúccolo, Descriçño histórica dos três réinos: Congo, Matamba e Angola trans. G.M. de Legguzano (2 vols.: Lisbon 1965), 1:190 (Book 1I, \#31).

14 Miller, "Imbangala," 568.

is In essence all the chiefs of Songo, including apparently the king of Bihe himself.

16 J. Graça, "Expedição ao Muatayanvua," Boletim da Sociedade de Geógraphia de Lisboa, 9 ( 1890), 391. 
This man lived in Nhâma, not far from Mathyanvo, when on the death of his father, who was chief of these lands, and as heir, he wanted to take possession of the polity; but his sister Manhungo as the older sibling opposed this and managed it so that her lover Mathyanvo adopted her opinion. Quingure could not resist him because Mathyanvo was powerful enough to frustrate all his enterprises. Whereupon he [Kinguri] resolved to retire to Cahunze, still a part of the polity, accompanied by the notables, Ndonga, Canguengo, Quibonde, Pande-ambumba, Quinda, Cahetecaquinzunzo, Gunza-abanguella, and Calanda who were accompanied by many people [or "villages"]..."

The story continues with an account of the barbarousness of Kinguri, which led Mwaant Yaav to expel him from his lands, from where he went to Cokwe country. There more sobas came to join him with their people. Among the names mentioned one finds Munjumbo-acafuze, Capenda-camulemba, Bumba-atumba, Ndumba-atembo, Malundo, and Mussongo-all titles of chiefs in the lands to the right of the Kwango by 1850 . Then Kinguri sent hunters westwards, who reported not only finding good lands, but also that Europeans had arrived at Cazanga [Luanda] in Queen Njinga's country with many goods. This attracted Kinguri and some of his chiefs. When he reached the Cuanza bend at Bola Cassache, however, he was murdered because of his cruelty by being locked in a house and then starved to death. His successor then made contact with the Portuguese.

Most of the story is new. The only old elements are the cruelty of Kinguri-now further elaborated-and the fact that he was killed. Now, however, he did not die at the hands of the enemy in battle and in Ndongo proper, but he was killed by his own followers, a fate that in the 1655-60 account befell his successor. Among the new elements one also notices the erroneous account of Njinga as ruler of Luanda. This refers to a Njinga myth first mentioned in 1778 near Luanda and current in central Angola during the nineteenth century. ${ }^{18}$

At about the same date another reference to Kinguri's exodus comes from Bihe. Here Magyar reports that the ancestors of the Ovimbundu left the lands of "Moropu" in the far northeast about 300 years earlier as a result of wars. They were led by "Kangouri" and "Schakambundi" and arrived at the Luando river in present Songo country. They were plunderers and cannibals. A portion of

17 A.R. Neves, Memoria da Expediçđo a Cassange ... em 1850 (Lisbon, 1854), 96-97.

14 Paulo Martins Pinheiro de Lacerda, "Noticias do Paiz de Quisama,"Annaes do Concello Ultramarino (Parte ndo official) (1846), 123-25. 
the people rebelled against this way of life and formed a secret society, and after a civil war emigrated to Malemba and Kissendi Massongo. There they multiplied to the extent that some chiefs, among them the first ruler of Bihe, later slowly migrated further and further southwest. The other half of the original population in Songo land then went to Cassange. ${ }^{19}$ Note that Magyar's account of ca. 1850 only finds a faint echo in the remark of Silva Porto, resident in Bihe since 1839 or 1840 , that the population of Bihe and Gallangue was a mix of Humbe, Ovimbundu, and Imbangala. ${ }^{20}$

So by ca. 1840 Kinguri was being linked both to Queen Njinga and to an unknown other line, probably one east of the Kwango, and by 1850 early versions of the exodus were current in Cassange and in Bihe, both centers of intensive trade with Lunda at the time. But the story was not yet fully tied in with any Lunda tradition. For Neves, Kinguri came from Nyama, a site of origin associated with Cokwe, Lwena, Mbunda, and Luchazi, while Magyar mentions the vague title Muropo, which referred to Mutombo Mukulu, a Luba kingdom beyond the Rund kingdom, rather than to the Mwaant Yaav himself.

Some twenty-five years later Pogge acknowledged that his record of the Kinguri story came from Lourenço Bezerra, who was also one of the main and earliest informants in general of Carvalho. Hence these two are not wholly independent accounts even if Carvalho undoubtedly heard the story from others as well. ${ }^{21}$ Bezerra was an African trader, originally from Golungo (hence labeled as "from Ambaca"), established in Lunda country by 1848 and at the capital by ca. 1849. He was the head of the Ambaquista traders in the country and became the close confidante of Mwaant Yaav Muteba. He left Lunda in 1876 but still met Carvalho, perhaps in Malange where he had settled, perhaps again at the Lunda capital. He died in $1885 .^{22}$

19. Lászlo Magyar, Reisen in Süd-Afrika in den Jahren 1849 bis 1857 (Pest 1859), 266-69. A comparable tradition was later reported by $\mathrm{H}$. Capello and R. Ivens, From Benguella to the Territory of the Yaccn, trans. A. Elwes (London, 1882), 157-58, but the leader here was Muzumbo-Tembo.

20 M. E. Madeira Santos, editor of A.F. Ferreira da Silva Porto, Viagens e apontamentos de um Portuguese em Africa (2 vols.: Coimbra, 1986), 1:282.

21 Pogge, Im Reiche, 224; Carvalho, Ethnografia, 538, 577, 578, 585, 590, 595, 622-23. Carvalho does not explicitly acknowledge Lourenço Bezerra as a source, contrary to the impression conveyed in Thornton, "Chronology," 2-3, note 14. But António Bezerra, his kinsman, was the official interpreter of the expedition (Carvalho, Viagens, 104).The other main source which Carvalho acknowledges as "later than Bezerra" was the latter's kinsman, Rocha. Moreover, it is evident from all his reports that Ambaquistas in general were his main advisors and guides.

22 Vellut, "Lunda," 133-34. 
It seems quite possible that it was Bezerra or his companions who introduced the story of Kinguri to the Rund court, perhaps around 1850, and helped to integrate it into an overall Rund tradition of origin which mentioned the disinheritance of sons in favor of a daughter. It probably was Bezerra who convinced Mwaant Yaav Muteba, or perhaps even an earlier king, to give it the stamp of official approval. For Bezerra told Pogge "that the deceased Mwaant Yaav had particularly liked to use the opportunity to tell him [Bezerra] about the origin of his kingdom. ${ }^{23}$ In any case mention of events which had once occurred in the colony of Angola, particularly the myth of Njinga's exodus from Luanda, had to come either from Ambaquistas or from Imbangala traders, at least if Pogge or Carvalho themselves did not add this information to their rendering of the tradition. ${ }^{24}$ In view of all of this, there is little doubt that the story of the Kinguri exodus from Lunda is an Ambaquista and Imbangala fabrication that first took shape in the 1840s in Cassange, in Songo country, and in Bihe, the termini of the major trade routes from the Lunda commonwealth.

One can only speculate as to why this tradition needed to be elaborated at that time and in those places. In the context of the slave trade, it was advantageous for traders from the Kwango to have kinsfolk inland, as the actions of king Mujumbo aKalunga show. After he had established trading contacts with the potentate Luinhame (Kinyama) of Louvar (Luvale), he then (ca. 1797) sent some of his men to Lovale to ask for the hand of a daughter of Kinyama so as to "strengthen the links of friendship with those of kinship." ${ }^{25}$ Perhaps the next best link was a trader's tale to show that he was not really a stranger but a long lost ethnic brother.

Still, the slave trade with the Rund was quite old, so why had such a tale not developed earlier? There were other factors at work. In the decades after the arrival of Rund ambassadors in 1807, the Lunda gradually acquired a great reputation in Luanda as a paragon of civilization. Such opinions in Luanda carried great weight among the Mbundu and others inland because to them Luanda was the acme of refined living. Therefore, the exodus tale of Kinguri may well have developed at first to raise the esteem of the Imbangala, Songo, and even Bihe rulers by deriving their rule from Lunda emigrants. Later the Rund adopted it because it turned the

23 Pogge, Im Reiche, 224.

24 Carvalho, Ethnografia, 1:77, mentions Njinga and "the already established fort of Massangano." Pogge, Im Reiche, 225 ,"Ginja."

25 "Exploraçōes dos Portuguezes no interior d'Africa meridional," Annaes Maritimos e Coloniaes, parte nđo official, 3a/6 (1843), 238-39. 
traders from the Kwango into lost subjects, over whom the Mwaant Yaav could now also claim some paramountcy, while in return the fictive ethnic tie helped them in Lunda lands.

The fact itself that the Rund adopted this alien Kinguri exodus story is not surprising. Such adoptions were not uncommon. This one also happened to the Pende of Kasai, who not only adopted the story of the Kinguri exodus, but also adopted the additional story that Kinguri had driven their ancestors out of the basin of Cassange. These ancestors, the Pende elaborated, had therefore lived near the Portuguese and hence had to be their kin, so that in faraway Kasai by 1884 they welcomed the first European they saw there as their "cousin." ${ }^{26}$ Indeed even the distant Kuba incorporated some Imbangala anecdotes into their corpus of history, such as a description of the tides and of the ocean shore or details about the outfits of the white men who drove the Kuba away from the ocean. ${ }^{27}$ The Kuba accepted such information because it fit so well with their conviction of a genesis near a primordial sea and war against evil people who had chased them from eden. The new information was interpreted and accepted as additional "revelations." A similar attitude also led the Rund, the Pende, and others to accept the exodus of Kinguri. It fit in with earlier accounts of origin and it 'explained' the presence of these foreign people in the world. So the new tale rounded out the etiological genealogies and tales that accounted for the political geography in the present. ${ }^{28}$

More amazing perhaps is the fact that all the courts which linked themselves to the Rund adopted this story, thus spreading it over a huge area. In part Carvalho was responsible for this. Not content just to relate a Rund version of their history, he presented a fullblown historical reconstruction, also based on his own gathering and interpretation of data of the courts of various Lunda subgroups in northern Angola, Imbangala, Shinji, Cokwe, and even Lwena. ${ }^{29}$ There are few other early records of oral traditions in these areas. Capello and Ivens give us two dating from 1879, one each for a major Cokwe and a major Songo court (with claims on Bihe). Kinguri was not mentioned by either, although the leader in one case was said to have come from the Rund court ("Lucoquessa") and in the other "from the north." 30

26 "Mueller's Bericht über seine Reise zu Muata-Kumbana" in Hermann von Wissmann, $l m$ Innern Afrikns (Leipzig, 1891), 101 (Kahungula's report), 108 (Pende want to meet their "cousin").

27 Jan Vansina The Children of Woot (Madison, 1978), 37.

2k See below; for instance, the genealogy explaining the position of Mai.

24 Carvalho, Ethuographia, 59-102.

31) Capello/Ivens, Benguella, 1:157-58; 190-92. 
The next record known was recorded at a minor Cokwe court in $1903 / 04$, to which is added presumably somewhat later information obtained from nearby Luchazi chiefs. The Cokwe court claimed that Tembua Tchissengue fell from the sky in the present country of the Mwaant Yaav and left five sons and one daughter, the ancestors of the major Cokwe chiefs, who migrated and later met the "lundasbangalas" chiefs Muhuri and Quimbundo. Even if Muhuri is Kinguri, which is unlikely, there still is no Kinguri exodus story here. As to the Luchazi chiefs, they did not mention any Lunda connection at all..$^{31}$

All other known and surviving accounts in the whole area of the western Lunda expansion were recorded after 1920, and all duly include Kinguri and his exodus. They include stories from courts pertaining to nearly all the peoples in the area..$^{32}$ By then the spread of the Kinguri exodus story was complete. One suspects that its spread was unconsciously facilitated by colonial administrators in the Belgian Congo, Angola, and perhaps Northern Rhodesia.

\section{III}

How seriously has the insertion of the Kinguri exodus story affected the corpus of oral traditions to which it was added? As far as one can judge, its insertion seems not to have required any alteration of earlier existing traditions at all, with the exception perhaps of the Rund proper. Elsewhere the Kinguri exodus story has been placed at the outset of the corpus, at the point that occurs in all traditions, namely, the departure of the later chief(s) from a primordial home identified as Kola in all the traditions from Kwango, Kwilu and northeast Angola; as Nama or Nyama in Lwena, Mbunda, and many Cokwe traditions; and as Candembe in modern Songo traditions. ${ }^{33}$ The older traditions in the northern part of the western Lunda commonwealth, except for the Rund corpus, seem already to have had exo-

31 Fonseca Cardoso,Em terras do Moxico (Porto,1919), 14-21; text reproduced in M.-L. Bastin Tshibinda llunga, héros civilisateur (2 vols.: Brussels, 1966), 2: xxvii-xxix. This text from 1903-04 was recorded at a minor Cokwe court .

32 No accounts from any Minungo chief are available, nor are records after 1920 for Shinji or Luchazi. Hoover, "Seduction,"19n19, mentions an archival reference to an otherwise unknown 1916 report that apparently was a draft of a draft (1928) of a 1938 article on Rund history.

33 Hoover, Seduction : 215, 219, 220. 311-15; Robert Papstein, "The Upper Zambezi: A History of the Luvale People,1000-1900" (PhD., University of California, 1978), 129-30 ("Nama-Kungu" clan); idem., ed., The History and cultural Life of the Mbunda Speaking Peoples (Lusaka, 1994), 1 (Kola, chieftainess Naama); Neves, Memoria, 96 (Nhâma); A.A. de Magalhães, "Origem dos Basongo," Mensário administrativo,15 (1948), 34 (Candembe). 
dus stories focusing on the Rund capital, so that attaching Kinguri to them did not produce further alterations within this corpus. But in the southern part, where Nama or Candembe were listed, this was not necessarily so. There may not have been any link between Nama/Nyama and the Mwaant Yaav before the Kinguri story was added, and there apparently was none between Candembe and the Rund capital.

Adding the Kinguri exodus meant that Nama now came to be linked to the Rund capital. Robert Papstein has shown that such a link with the Rund capital was stressed more and more during the colonial period and afterwards because it served Lwena and Cokwe political interests in Northern Rhodesia and the Belgian Congo. ${ }^{34}$ But this merely constituted another addition to the older corpus of traditions, leaving their content unaffected. Of course this conclusion does not mean that the older corpus constitutes an unvarnished and totally unaltered "truth." Certainly the general dynamics of oral tradition in these areas, which 'explains' the political geography of the present and therefore changes with the fortunes of the local chiefdoms, have affected the contents of this 'older corpus' as well. The reliability of each traditional statement will need to be studied in its own local context to a greater extent than has happened so far in many cases.

The Rund corpus itself may have been more affected. Hoover has shown that the Rund renderings of names such Kinguri, Chinyama, and others such as the Chokwe name Ndonji are all loanwords imported into the Rund corpus. He concludes that "the connections among the Ruund, Mbangala, Lwena, and Chokwe, through a supposed set of 16th century siblings are instead a collection of 18th and 19th century fabrications." ${ }^{\prime 35}$ At the very least the names Chingud and Chinyam were given to the earlier unnamed sons whom the Rund ruler Nkond excluded from succeeding him because they saw him naked when drunk and did not cover him up.

This is the biblical Noah story-itself likely to have been imported by Ambaquista or perhaps Imbangala traders. Its ostensible etiological goal, which is to explain why succession is matrilineal, does not fit well with the actual succession at the nineteenth-century Rund court. Perhaps it had been borrowed some time before the 1840s to explain how the first Rund ruler was a woman Rweej. Or perhaps the Noah tale was imported around the same time as the story of Kinguri and provided the motive for his eventual exo-

34 Papstein, "History," 30-50 (Lovale in northern Rhodesia); Hoover, "Seduction," 303-05 (Cokwe, 1960).

35 Ibid., 214-26. 
dus. As to his companions, Carvalho or the Rund court added known ancestral names of Cokwe and Lwena when they created the Kinguri exodus story or a little later. But in this case too the insertion of the Kinguri exodus story consisted merely in a set of additions to an existing Rund corpus of traditions that dealt with the seduction of Rweej by Chibinda Ilunga and the foundation of the realm. It did not require any further changes in that corpus either to the earlier period of genesis or to the later traditions about kings. The impact of Kinguri remained limited-unlike what Kinguri did to scholars!

For the impact on scholars was incomparably of greater moment. ${ }^{36}$ The Kinguri exodus tale had provided them with an implied chronology for the history of the whole region, and has ruled out any link between the Lunda expansion and the slave trade, because the date of his departure could not be placed after $c a$. 1600. But now that Kinguri and his companions are gone, this chronological anchor is gone as well. One may even begin to wonder whether there was ever a Lunda expansion?

Even a cursory examination of the area claimed to have been in the western part of the Lunda commonwealth reveals three different situations. First, in the northern part of that area the Rund language is still spoken or a strong Rund linguistic influence, especially at the courts, testifies to genuine Rund settlement and conquest. There the local rulers are said to have been sent out from the capital "in pursuit" of Kinguri. This contrasts with the southern part of the area, where there are only traces of Rund linguistic influence, especially for some political titles and emblems. Here one can doubt whether any conquest and incorporation into a Lunda state ever took place. Finally in a small area to the north and northeast of the heartland there exists but little Rund linguistic influence and the first ruler is linked only as a supposed brother to the very first Rund ruler. While this is evident in the case of the Kanyok and Luba Mutombo Mukulu kingdom, it also holds for the small principality of Mai, then south of the Kasai upstream from the confluence of the Tshikapa river, even though this principality had practically come under Rund hegemony by the $1870 \mathrm{~s}^{37}$ These polities were clearly outside of the commonwealth and are no longer discussed below.

3. I do not discuss the impact of the story on the historiography of Angola here. Suffice it to say that the demise of the Kinguri exodus requires major revisions to Miller's Kings and Kinsmen.

37 Schütt, Reisen, 136. Mai was the youngest son of "Mutombo Mucalla" [Mukulu] 
As to the expansion and its dating, one early document directly attests to the reality of an expansion from the Rund heartland. In 1756 Leitão mentions the Mataiiâmvua and states that

[t]his Molua is very powerful and captains sent by him to the west, to the north and to the south and to other parts with troops of very numerous people come forth from his principalities and dominions to capture [conquer] slaves which they sell to the region which is the closest to where they take them, such as towards Benguela and towards the parts where they travel for Cassange, for the Olos, even for the kingdoms of Congo, So.Sos, Quiiacas, quilubas, ungus, which he has all put below his strong sword, so brave and feared by the destruction they have wrought in all the dominions as many as they are, that the mention of their name suffices for them to overcome; in such a manner that today they come to sell people [gente] on the borders of the lords Ambuela and Mutemos; really tall men and so famous among the nations of all those extensive forests, that one does not speak of anything else; it is certain that were it not for them we would not have so many slaves, because they, moved by their ambition and renown to conquer, circulate in lands so far removed from their fatherland, turned into terrestrial eagles, merely to become masters [senhores] of other peoples [gentes]. ${ }^{38}$

A Lunda or Molua ${ }^{39}$ domination then can hardly be doubted, although one should note both that the "conquests" of "people" refer to slave raids, not to the incorporation of polities, and that the expansion was obviously still ongoing. Leitão's report also refers to the northwestern parts of the Lunda commonwealth, the part which the Rund really settled, and says nothing about the whole area south of $9^{\circ} 30^{\prime}$ south, i.e., nearly the whole of eastern Angola.

1756 provides unequivocal written evidence about a Lunda expansion, but when did it begin? The earliest mention about it was written in 1681 or somewhat earlier. Speaking of the Imbangala of Cassange, Cadornega tells us that those who went out in the vast bushlands to the east reported that the Imbangala went out east-

and a brother of Muene Canchica (Kanyok), Muata Cassongo (the main Luba ruler in Katanga) and "Quibinda Ilunga." See also ibid., 145, 150. All other known references to Mai's supposed origin agree. In 1855 Livingstone noted that Mai was an independent chief. Isaac Schapera, ed., Lvingstone's African Journal (2 vols.: London, 1963), 2:245. For the fullest account see Carvalho, Ethmographin, 98-99.

3* M. Correia Leitão, "Viagem," in G. Sousa Dias "Uma viagem a Cassange nos meados do século XVIII," Boletim da Sociednde de Geografia de Lisbon, 56 (1938), 25. Leitão's report (ibid., 9-30), which dates from 1756, is not well known and its contents are frequently misunderstood, despite J.-L. Vellut's "Relations internationales du Moyen-Kwango et de l'Angola dans la deuxième moitié du XVIIIe s.," Etudes d'Histoire Africaine, I (1970), 75-135, which is devoted to an analysis of this report.

3y Dias, "Viagem," 10 ("aluluas"), 25 ("molua"), and 2828 ("maluê"). Molua soon became the standard designation. 
wards and had heard of the Kasai river "one month eastwards." They also met people who came from the other bank (it is unclear whether the Kwango or the Kasai river is meant) to trade their cloth for salt: ${ }^{40}$

which people they call Muzuas and they say that they are vassals of a very powerful lord; to the extent that several times, when they came to Casangi's camp [kilombo] with the trading goods mentioned, he took a few of them to eat them; and such is the quantity of this people that they did not cease to come because of this and when they tell to their lord, of those that remained [behind] as casualties, he answers that it does not matter, that Casangi is hungry; and this our Jaga orders to give them gifts of clothing to keep them in a good mood and that the good intercourse and friendship not be damaged.

They also informed the conquering Jaga that in the heart of the bush, in which they spend three months of travel there exists a sort of people called Donges, a very valorous people, where they had lost three undertakings of their armies and been defeated and beaten by them. ${ }^{41}$ Cadornega goes on to say that that much beyond the lands of these people there was a sea or Calunga, with some big ships and a fort called embaca from which Cadornega erroneously concludes that this must be the east coast and the Donges a people in Mozambique. ${ }^{42}$

This information, like that for 1756 , is based on hearsay and not fully reliable. Still, the mention of the Kasai as very large must refer to the river where it now forms the boundary between Angola and Congo. The Muzua probably are the Rund or a subgroup and the powerful lord, probably the Mwaant Yaav. The mere fact that a kingdom beyond the Kasai was known as far away as Cassange indicates that it must have been quite sizeable. That its inhabitants came to trade at Cassange points to a farflung Rund commercial network, but also implies that the appeal of the Atlantic slave trading area had already reached quite far inland and could have played a role in the direction of the Lunda expansion.

411 Almost certainly raffia cloth. If so, this is the earliest known reference to raffia cloth from beyond the Kasai river. Note that slaves are not mentioned but probably were already a major object of trade.

11 Donge could refer to several Ndonji titles and territories in Angola, e.g., to the areas later labeled Cokwe or Minungo, or even to the Jaga realm in northernmost Matamba mentioned by Cavazzi, Congo, Matamba e Angoln, 1:21, 177; 2:196: (books I:16; Il:4,6, VII:31).

42 A. de Oliveira de Cadornega, História geral das guerras angolanas (3 vols.: Lisbon, 1942), 3:219-20. The original dates to 1681 . Embaca obviously refers to Ambaka, the fort in Angola, and Calungn, "sea," as well as the term cited for "ship" are kimbundu, hence the tales refer to Angola, not to Mozambique. 
The report about three campaigns against the Donges indicates that the Muzua kingdom had begun to raid, if not to expand, while its successive defeats show that it was by no means very powerful yet. So by 1680 Lunda expansion had begun, but the Lunda were not yet particularly powerful. Hence we can reasonably assume that the expansion began at the latest ca. 1670, and that the earlier fullfledged Rund kingdom is probably at least a generation or so older. The small chiefdoms along the Nkalaany river out of which that kingdom arose are earlier than that. It is not unreasonable to claim that these chiefdoms themselves appeared at the very latest $c a .1600$ and are probably much older.

Accepting the Kinguri exodus story implies that the expansion had started before, or at the latest by, 1600 and historians studying the political realms founded by the companions or pursuers of Kinguri had all accepted this chronology, and in several instances had forced their data somewhat to fill the gap between $\mathrm{ca} .1600$ and whatever later date they obtained from internal evidence. By removing Kinguri, one removes this dating and the way is now open to establish more realistic chronologies based on the internal evidence for each of the polities concerned. Whatever future investigations may reveal on this score, it is already clear that these polities began in the eighteenth century and not in the seventeenth. ${ }^{43}$

When did the process of Lunda expansion finish? The 1756 text makes clear that the chiefdoms on the east side of the Kwango river, who were constantly at war with their neighbors to the east, had not yet been subjected to the Lunda, rather than falling to Lunda rulers at the very outset as the Kinguri exodus stories would have it. ${ }^{44}$ Western Lunda expansion was then still in progress. According to several reports from 1762 onwards, Lunda warriors reached the Kwango river and the limits of their expansion in this direction dur-

43 Several authors have studied the internal chronology of the Yaka kingdom in depth. In the latest effort H. Van Roy, Les Byambvu du Moyen-Kuango (Berlin, 1988), $73,178-79$, concluded that Muteeba Ndziimbu was the first king who began to create a stable state and dates this process to 1710-1740/50. Considering Leitão's evidence, the closure date is only a little too early. As a result, the proposed later chronology of the Yaka kingdom and surroundings seems to be only twenty years or less too early. In contrast, not much attention has been paid to internal chronology elsewhere and the proposed datings need to be shortened, sometimes by a full century, to the mid(or in the Mbunda case perhaps even to the late) eighteenth century.

44 Dias, "Viagem," 19-21. The fact that the title of the Shinji lord Malundo was claimed to be imported by Rund conquerors in Carvalho's time should not be taken to mean that this was already so in 1756. The fact that Leitão distinguished Malundo and the other realms just east of the Kwango from the Rund, to the point that he gives separate ethnographic descriptions for each, suggests that the title and the dynast of 1756 was not of Rund origin. 
ing the 1760 s. $^{45}$ Later the itineraries of travelers between 1793 and 1814 in both the northern area discussed by Leitão and in the whole of eastern Angola further south show us that the state of incessant warfare portrayed by Leitão no longer prevailed. Obviously, the main Lunda expansion to the west had run its course by then. By 1814 the Rund homeland was bounded by the upper Kwilu and the upper Kasai rivers. ${ }^{46}$

It is striking that not a single written document before 1846 refers to any Lunda conquest in what is now eastern Angola, even though various data about Cokwe and Luvale country from ca. 1793 onwards are reported-striking, that is, in contrast to the north, where the "Molua" are constantly mentioned along the Kwango after 1762 and duly appear on the earliest map (1786-90) and all later maps of those regions. One can reasonably conclude that there was no Lunda expansion to the south at all. Certainly there was no Rund settlement and no large-scale military irruption there. Once one rejects the traditional evidence about Kinguri's companions, as one must, there is no evidence that any of the many chiefdoms in this vast area were either founded or more modestly taken over from autochtonous chiefs by Rund migrants. There never was any Lunda expansion to the south.

The story in the south has been one of stimulus diffusion, of the adoption of Lunda political customs such as titles or emblems or parts of the Lunda boys' initiation ceremonies. But because it has wrongly been assumed that Rund chiefs automatically imported these things, the full extent of this process and its chronology remain largely unknown and unstudied. At this point one can only surmise that the enormous Rund prestige evident by 1750 provided a reason for others to imitate them, while the roads and trade from the chiefdoms in eastern Angola to the Rund capital, created by and for the slave trade, provided the opportunity to observe and borrow. The borrowing may well have been piecemeal and the whole process of long duration. Indeed it may well have continued until the waning decades of the nineteenth century.

The Kinguri exodus tradition took shape in the 1840 s among the

45 David Birmingham, Trade and Conflict in Angola (Oxford, 1966), 150 (1762), 152-53 (1767). Thornton" Chronology," 8, 13 n53 (1762) is incorrect in talking about a flood of refugees "from the 'Moluas'."

th For these sources see Vellut "Relations" and "Lunda". Also Jan Vansina, Kingdoms of the Savannn (Madison, 1966), 217 (map with limits of Rund homeland before the mid-nineteenth century). 
Imbangala and the Songo to their south, presumably to ally the prestige of Cassange to that of the faraway Lunda and perhaps to facilitate trade. By 1920 the exodus tradition had been adopted in the whole area of western Lunda influence. As earlier traditions already had stressed the origin of chiefs, and hence of their legitimacy, in a foreign nuclear area, whether Kola (i.e. the Rund heartland in the north), Nama in the southeast, and probably Candembe among some Songo, another exodus story sounded familiar and was easily incorporated in most cases. Yet one is amazed by the extent of the huge area in which the corpus of previous traditions was altered to adopt this new story, until one realizes that the peoples in the whole area were united by their participation in the common slave trade and that the Rund capital was the major interior hub of the common web. Once the tale had traveled to that hub, it could also be disseminated from it to the whole periphery.

In addition, the way in which Kinguri was fitted in the older corpus, provided with siblings and kitted out with ancestors does throw doubt on interpretations of oral traditions which claim that they accurately render past political situations and unchanged by the use of a conventional idiom of perpetual kinship and positional succession. Rather, the fate of the Kinguri story strengthens the alternative view that such genealogical political arrangements merely reflect the political landscape of the time and do change as that landscape changes. Hence such genealogies are useful to elucidate the political geography of the time. Thus the list in Neves' account of the 'companions' whom Kinguri left behind does give us a spatial panorama valid for 1850 . At that time the three later main Shinje chiefs and a number of Minungo, Songo, and Cokwe rulers as far away as the sources of the Kwango itself are already there, as we discover when we recognize them on much later maps. ${ }^{47}$

The Kinguri exodus tale does forcefully remind us that traditions do not remain unchanged, but are altered to fit changing circumstances. Rather than conclude from this that traditions are useless as sources for history, one should take advantage of their character as palimpsests to peel off the latest layer when one can, as in the Kinguri case, and obtain a clearer reading of what earlier messages were. The most obvious example of this concerns chronology. Without a Kinguri story one has to fall back on chronological indicators in the internal evidence which should have been studied more seriously than they have been. But much more is at stake here than chronological adjustment! The Kinguri exodus story had the effect

47 Neves, Memória, 98. The Shinji names occur in Carvalho, Ethnographin, 92-93. Practically all the others are found on map 2 of Schütt, Reisen. 
of implying that the steamroller of Lunda political civilization had in essence created the political structures everywhere else in the whole area. But once the veil is lifted, one realizes that the older traditions refer to several older political centers rather than to a single one, and point to a situation in which autochthonous elements played major roles. ${ }^{48}$

Eliminating the Kinguri exodus feature also leads to the following further realizations. First, that while a genuine Lunda expansion occurred in the north, the south knew neither conquest nor settlement, but only an influx of Lunda influence. Secondly, the Lunda expansion and the spreading of Lunda influence was undoubtedly linked to the slave trade. These are major upheavals and they underscore the magnitude of the impact of that trade. Yet the full dynamics and the effects of the slave trade on the specific peoples, societies, and cultures in this vast area remain practically unstudied. In the end lifting the Kinguri veil exposes the crying need for indepth research in most parts of a vast area whose history we thought we knew. We can only reflect ruefully that, if the Kinguri story had only been subjected to critical appraisal from the outset, we historians would now be much more advanced than we are.

t* This point cannot be developed here. Still, briefly, there was a "Lovar" type between the upper Kasai and uppermost Zambezi, a "Kwango" type along the latter, a Pende type along the middle Kwilu, and a Munjumbo a Kalunga type between the uppermost Cuanza and the Cunene. 